\title{
Serine/Threonine-Protein Kinase N1
}

National Cancer Institute

\section{Source}

National Cancer Institute. Serine/Threonine-Protein Kinase N1. NCI Thesaurus. Code C125199.

Serine/threonine-protein kinase N1 (942 aa, 104 kDa) is encoded by the human PKN1 gene. This protein is involved in post-translational protein phosphorylation. 